in soft tertiary marls" it may be inferred that the streams are little advanced in their present cycle of development. Professor Hicks postulates that at the beginning of the current cycle of river history, the several branches of the Loup River all pursued independent courses to the Platte. The origin of those early courses is not stated; whether they were consequent on the slanting surface of the tertiary marls, or whether they represented the finally adopted positions of old rivers of a previous cycle of growth.

Old rivers, revived by the uplift of the plains into a new cycle of growth are common enough in the western country, and perhaps the Platte and Loup may be of that kind; but, if so, it does not seem possible to explain the present course of the main Loup River as resulting from a recent capture of its several north-west branches. River captures occur during the early maturity of a river system. If the Platte and the Loup are revived from the old stage of a previous cycle, the captures should have taken place in the earlier part of that cycle; and when the river courses had thus become well adjusted, they would be maintained even after uplift and entrance into another cycle, unless distinctly new conditions were thereby introduced. The possibility of this will be considered in a later paragraph.

If the rivers are not now in a second cycle of development, but are in their first cycle, having first taken their course when their region rose from the waters in which its strata were deposited, and having since then done nothing more than cut their shallow trenches in the general unbroken surface of the country, then we must ask whether their initial courses must have been in the arrangement postulated by Professor Hicks, or whether they may not from the beginning have had courses essentially on their present lines of flow. This latter alternative appears to be indicated at the end of Professor Hicks's article, if I read it aright. Assuming that the last great tertiary lake not only submerged the area of the Loup River, but spread its lacustrine sediments over the surface so as to obliterate any channels of earlier date, then on the disappearance of the lake, the rivers would be newly developed on the faint slopes of its deposits. The Platte, bringing down silt in large amount, may have been at that time a construc. tive river, busied in building up a broad delta-like flood-plain, further and further out on the lacustrine deposits as they were revealed. If so, it would turn its lateral tributaries down-stream, and the existing arrangement would be produced without the aid of headwater erosion and capture. Hence, until the process of flood-plain deflection is excluded, it does not seem necessary to include the process of headwater erosion and capture.

But even if it be supposed that the courses of the rivers at the beginning of the present cycle were arranged as postulated by Professor Hicks, and that all of them from the Beaver to the South Loup entered directly into the Platte, it seems impossible to explain their present arrangement by the headwater erosion and piracy of the Loup. The conditions for so systematic a process do not occur in the region under consideration, as will appear from the following analysis.

In the first place, it is important to remember that it is not the river but the little trickling headwater streams on the slopes of the divides that do the capturing in cases of the kind here discussed. The capture of one river by another, or lateral abstraction, as described by Gilbert in his most original examination of this problem in his report on the Henry Mountains is a comparatively rare occurrence, and is not applicable here.

In the second place, capture by little head waters is most common in regions of tilted rocks of varied hardness, and on the headwaters of "subsequent" streams; that is, streams whose headwater-growth is dependent on the opportunity given by the weathering of some especially weak stratum, along whose strike the stream extends. No such special opportunity has been offered to the Loup River in this region of horizontal beds.

In the third place, as one headwater stream grows, all other adjacent headwaters of the same kind grow at about the same pace. Hence, if the Loup River has so greatly extended itself by headwater erosion, all the other headwater streams should have grown also, and the country thereabouts would be much more dissected by channels than it now is.
Finally, the location of Prairie Creek seems to contradict the supposition that the branches of Loup River ever joined the Platte directly; for, if they had, then Prairie Creek must be, like the supposed extension of the Loup, an example of headwater erosion; and this is not to be thought of in a stream so systematically located between two parallel and larger rivers in a district of horizontal beds.

Taken all together, it does not seem necessary to give any especial emphasis to headwater erosion and capture in this river system. The natural result of excessive deposition along the Platte, as described by Professor Hicks, is alone sufficient to account for the present arrangement of the streams. The growth of the Platte flood-plain may have dammed back some of its tributaries, as certain branches of the Red River in Louisiana are dammed back and converted into shallow lakes; and the present main Loup River would then be developed by lateral overflow along the margin of the flood-plain; but this is quite another process from headwater erosion and capture.

These suggestions are only tentative; for not having seen the region and having no full account of its geological history or of its topography, I can only submit them for criticism.

Harvard College, Feb. 10.

W. M. Davis.

\section{Origin of the Frigid Period in the Northern Hemisphere.}

IN my letter, published in your issue of Oct. 16, I stated that the independent circulation of the southern ocean waters was the main cause of ice-sbeets forming on the lands situated in the high latitudes of the southern hemisphere; and that such currents were caused by the strong westerly winds, which blew the surface waters of the southern ocean constantly around the globe, and thus prevented the tropical surface currents from largely entering its waters. Consequently, through this cause and the constant gathering of ice in the antarctic regions the temperature of the southern latitudes was stowly lowering; and that the growing coldness would continue until the southern ice-sheets filled the Cape Horn channel and prevented the further independent movement of the southern ocean waters. This being accomplished, the westerly winds would blow the surface waters of the sea away from the eastern side of the ice-formed isthmus and the southern lands of South America, and so cause a low sea-level, that would attract the surface waters of the tropical seas far into the southern latitudes, and thus in time furnish heat sufficient to melt the ice from the southern lands. I also stated that an ice period could not be perfected in the northern hemisphere without the assistance of cold derived from a frigid period in the southern hemisphere. The independent circulation of the arctic waters is not complete, owing to land obstructions; but it is able to largely prevent the tropical Gulf Stream waters from entering the higher northern latitudes. The prevailing westerly winds blow the surface waters of the Atlantic away from the eastern shore of North America from Georgia to Labrador; consequently the low sea-level thus caused attracts the high-level tropical waters of the Gulf of Mexico through the Florida channel well into the northern latitudes; and during the same time the westerly winds which blow the surface waters of the Atlantic away from the American coast are also causing a high sea-level on the seas abreast north-western Europe, which creates a return current through the Arctic Ocean, passing through the several straits leading into Baffins Bay, and also down the eastern coast of Greenland. Thus the ocean waters of the high northern latitudes maintain a partly independent circulation, which serves to crowd the Gulf Stream away from the higher latitudes, and thus lower the temperature of the arctic regions. Through this exclusion of tropical waters, glaciers have formed on Greenland and other arctic shores; and these glaciers are probably slowly increasing, as every iceberg launched from the frigid lands and floated to the Gulf Stream lowers somewhat the temperature of the north Atlantic, and so causes conditions more favorable for larger accumulations of ice. Still it is probable that a northern ice period could not be perfected by this process alone should the tropical and southern oceans maintain their present temperature. But with the assistance of a frigid period in the 
southern hemisphere to cool the ocean waters and still further lower the temperature of the Gulf Stream, and also the tropical currents of the oceans, including the great Japanese current, the ice period of both hemispheres would be brought about during the same era. For it is well known to those who have studied the subject that the Gulf Stream derives a large portion of its heat from the south Atlantic; which would not be the case should the waters of the southern hemisphere be chilled by ice. For it appears that all of the south Atlantic islands during frigid times were burdened with glaciers. Even the island of St. Helena, situated in the tropical zone, has the appearance of having been heavily iced during some remote period. Its steep ravines, which deepen as they approach the sea, recall to the southern voyager the iceworn islands of the higher latitudes. Thus when the temperate regions of both hemispheres were heavily iced the temperature of the tropical seas must have been comparatively low, especially on the eastern sides of the oceans which are swept by the polar currents. Moreorer, the sea was much salter than now, on account of a large portion of its waters being absorbed by glaciers. Furthermore, whenever the arctic channels are filled with glaciers the inderendent circulation of the arctic waters must cease; consequently the Gulf Stream, meeting with less opposing polar currents on its sweep northward, would thus be able to gain a much higher latitude than now. Although its waters at first would be colder than they are to-day; still their superior saltness would add to their ability for dissolving ice wherever they were able to flow. But it appears that the Gulf Stream and other tropical currents of the northern oceans would not be able to subdue the cold accumulated in northern ice-sheets without the assistance of a comparatirely warm ocean in the southern hemisphere. The southern seas being so much superior and so widely connected with the northern, the tropical currents of the latter seas would require the assistance of the southern oceans to subdue the cold of a northern ice period, in the same degree that it required their cooperation to bring about the frigid period. The arctic straits, which now facilitate the independent circulation of cold Arctic waters, would, when filled with glaciers, be slow to thaw out, even with the increasing warmth of the arctic regions, on account of being situated to the wind ward of the warm gulf currents. Therefore, the glaciers that filled their deep channels would be the last great body of ice to melt in the northern regions; and for this reason it is probable that there are fragments of the old ice of the last frigid period still unmelted and now form a portion of the lower shores of the arctic straits. This conclusion is in harmony with reports from Point Barrow which inform us that a stratum of pure ice is found beneath the scanty soil. The low temperature of the waters of the tropical oceans during the perfection of a frigid period must have been very destructive to oceanic life; while such as survived probably found refuge in nearly landlocked equatorial seas, where the waters were largely excluded from the colder ocean, and also freshened by such rivers as emptied into them. Meanwhile, the low temperature of the ocean must have chilled the atmosphere over the land to such a degree as to have caused the destruction of many species of animals.

C. A. M. TABER.

Lake Como, Florida, Feb. 5.

\section{Electricity in Agriculture.}

THE abstract under the above title in Science for Jan. 15, 1892, which $I$ have only just found time to read, proves very interesting to me, and I do not wish in any way to have it inferred that I disbelieve in the influence of electricity, at least indirectly, upon the growth of plants; but it does not seem out of place to call attention to the fact that the comparative rarity of mildew on plants grown above electricity-bearing copper wires in moist soil may be due to the action of the copper salts formed in killing the mildew rather than to electrical action.

The roots of the lettuce in the experiment mentioned at "Garden A" (Science, p. 36) are stated to have "grown about the wires, as if there they found the greatest amount of nourishment," etc. This would also be the result from the roots seeking the environment best suited for growth, if the mildew could not thrive about the wires on account of the trace of copper salts which the soil contained.

The use of sprays containing copper salts, in the form of Bordeaux mixture or similar compounds, as a preventive of mildew of grape-vines and other plants is well known, and the control plot, "Garden B," should have been provided with copper wires, exactly as was "Garden A," to make the results of the experiment conclusive. As I have not seen the original article in the Bulletin of the Hatch Experiment Station, from which the abstract in Science was taken, it may be the fact that this action of the copper salts upon mildew has been discussed there.

Canobie Lake, N.H., Feb. 15.

Georae DIMmock.

\section{AMONG THE PUBLISHERS.}

E. \& F. N. SPON \& Co. announce "Roll Turning for Sections in Steel and Iron," by Adam Spencer. The subject of roll-turning is treated from a purely practical point, and for practical men. The drawings are the result of experience, and their value consists in the fact that they are working drawings, that is, drawings of rolls which have passed through the ordeal of actual work. The arrangement of the work is as follows: First, drawing of modern blooming for steel slabs, followed by a pair of billet rolls, then various sections showing the related grooves in cogging, roughing, and finishing rolls, with the position and character of collars required. "A Text-Book of the Science of Brewing," by Edward Ralph Moritz and George Harris Morris. The following extract from the introduction will show its character: "The object of this work is to provide in a convenient and accessible form such knowledge of the processes of brewing and of the materials employed in that industry as is at our disposal; and - so far as we are able - to connect such knowledge with the practice of brewing. We therefore intend it as a text-book in which may be found the results of scientific research together with the practical conclusions which we consider justly deducible from them. We do not pretend that a perusal of our work will enable a novice to brew beer; neither will a study of it convert a purely practical man into a chemist. It is meant, howerer, to lead the brewer to a better understanding of what we may term the physiology and pathology of brewing, and, by so doing, put at his disposal a means for more efficient control over his operations." "Manual of Instruction in Hard Soldering," by Harvey Rowell. "The Mechanical and Other Properties of Iron and Steel in Connection with Their Chemical Composition," by A. Vosmaer, engineer. The author has gathered together the widely scattered information on this important subject, and gives in brief outline the actual knowledge of the intimate connection that exists between the properties of steel and iron and their chemical composition. The elements carbon, manganese, silicon, phosphorus, sulphur, copper, chromium, titanium, tungsten, aluminium, nickel, cobalt, arsenic, antimony, zinc, lead, tin, silver, molybdenum, vanadium, potassium, sodium, barium, strontium, calcium, and magnesium - have been considered separately and in the following manner: First, as to the metallurgical behavior of the elements in question; next, to deal with their influence on pig iron, cast iron, wrought iron, and steel; lastly, the special uses made of them, and their occurrence in manufactured objects. The gases, intermolecular, reaction, and mixed, have been carefully considered, and analyses given of foundry, bessemer, basic, and forge pig-irons, spiegelirons, ferromanganese, ferrosilicons, ferrochromes, ferrotungsten, ferroaluminium, cast-irons, weld irons. Steel - railway material, structural steel, ordnance material, miscellaneous. With a diagram of silicon in cast iron, and of disappearance of carbon. Also a new edition of "A Practical Treatise upon Warming Buildings by Hot Water."

- Morris Phillips of the Home Journal goes abroad every summer for recreation and business. He has kept up that habit for nearly twenty years, besides travelling widely over this country, and as a result of his experiences he has just compiled a notebook of practical hints for tourists entitled "Abroad and at Home," in which he gives incidents of his travels, as well as a 